\title{
Efficient production of polymer-grade L-lactic acid from corn stover hydrolyzate by thermophilic Bacillus sp. strain XZL4
}

\author{
Zhangwei Xue ${ }^{1,3}$, Limin Wang ${ }^{1}$, Jiansong Jü ${ }^{3}$, Bo Yu ${ }^{1 *}$, Ping $X u^{2}$ and Yanhe Ma ${ }^{1}$
}

\begin{abstract}
Lactic acid has been identified as one of the top 30 potential building-block chemicals from biomass. Therefore, the search for cheap raw materials is an objective to reduce the production costs. Efficient polymer-grade L-lactic acid production was achieved in this report by a thermophilic strain Bacillus sp. XZL4 using corn stover hydrolyzate as sole carbon source. High L-lactic acid concentration $\left(81.0 \mathrm{~g} \mathrm{~L}^{-1}\right)$ was obtained from $162.5 \mathrm{~g} \mathrm{~L}^{-1}$ concentrated corn stover hydrolyzate (total reducing sugar of $83.0 \mathrm{~g} \mathrm{~L}^{-1}$ ) with a volumetric productivity of $1.86 \mathrm{~g} \mathrm{~L}^{-1} \mathrm{~h}^{-1}(0-36 \mathrm{~h}$ ) and a product yield of $0.98 \mathrm{~g} \mathrm{~g}^{-1}$ total reducing sugars. This is the highest L-lactic acid concentration and yield reported from corn stover hydrolyzate. And the high optical purity of L-lactic acid obtained in this study also indicated that Bacillus sp. XZL4 is a promising polymer-grade L-lactic-acid producer from cellulosic biomass.
\end{abstract}

Keywords: L-lactic acid, Thermophilic, Bacillus sp, Corn stover hydrolyzate

\section{Background}

Lactic acid is a valuable chemical and one of its extensive applications is for polymerization of L-lactic acid to poly (L-lactic acid), which is an attractive polymer because it can be produced from renewable resources and is biodegradable. These properties have strengthened interest in developing more efficient production processes for optical purity of L-lactic acid (Wang et al. 2010a). As lactic acid has been identified as one of the top 30 potential building-block chemicals from biomass (http://www.eere.energy.gov/biomass/pdfs/35523.pdf), the search for cheap raw materials is some of the most important objectives to be achieved to reduce the costs. To improve productivity and economy of lactic acid production, some reports have investigated the potential of utilizing low-cost raw materials as carbon sources, such as molasses and cellulosic materials (Patel et al. 2004; Romaní et al. 2008; Wang et al. 2010a). Corn stover, one of the lignocellulosic biomasses, is the agricultural residue left unutilized in harvested. Corn stover is not a food source and has high concentration of mixed sugars,

\footnotetext{
* Correspondence: yub@im.ac.cn

${ }^{1}$ Institute of Microbiology, Chinese Academy of Sciences, Beijing 100101, China

Full list of author information is available at the end of the article
}

mainly including glucose and xylose, and therefore it is considered as one of the most important global feedstocks for the production of chemicals in future (Georgieva and Ahring 2007). Furthermore, the addition of large amounts of yeast extract in lactic acid fermentation was also economically prohibited for producing such low-value biocommodities (Altaf et al. 2007). Various low-cost raw materials such as tryptic soy (Nancib et al. 2005), soybean hydrolyzate (Kwon et al. 2000), corn steep liquor (Nancib et al. 2001), whey protein hydrolyzate (Fitzpatrick and O'Keeffe 2001) and red lentil and baker's yeast cells (Altaf et al. 2006) have been investigated to substitute yeast extract for lactic acid production. However, most of the substitutes were not very effective. Therefore, development of an efficient and cost-effective process for lactic acid fermentation from cheap and non-food substrates is highly desired.

Bacillus species are the most widely utilized microorganisms for L-lactic acid production (Budhavaram and Fan 2009; Danner et al. 1998; Patel et al. 2004; Qin et al. 2010; Walton et al. 2010; Wang et al. 2010b; Zhao et al. 2010). As potential industrial strains, thermophilic Bacillus species offers several remarkable advantages for lactic acid production, including the reduction of contamination from competing microbes, simple nutrition requirements, 
and simple maintenance of stock cultures (Patel et al. 2004; Qin et al. 2009). In this study, corn stover hydrolyzate was chosen as sole carbon and different low-cost nitrogen sources (peanut meal, dry corn syrup and soybean meal) were tested as sole nitrogen source, respectively, for polyer-grade L-lactic acid production by a thermophilic Bacillus strain. The aim of this study was to develop an encouraging process for the economical L-lactic acid production based on cheap raw materials. The batch fermentation results of high yield and high optical purity of L-lactic acid from corn stover hydrolyzate indicated that Bacillus sp. strain XZL4 used in this study is a promising L-lactic-acid producer from cellulosic biomass.

\section{Results}

\section{Effects of corn stover hydrolyzate concentrations on} L-lactic acid production

Different concentrations of corn stover hydrolyzate with the total reducing sugars of 41, 53, 83 and $133 \mathrm{~g} \mathrm{~L}^{-1}$, respectively were firstly used to test the effects of corn stover hydrolyzate concentrations on L-lactic acid production. As shown in Figure 1, when the initial corn stover hydrolyzate concentration was below $162.5 \mathrm{~g} \mathrm{~L}^{-1}$ (total reducing sugar is $83 \mathrm{~g} \mathrm{~L}^{-1}$ ), L-lactic acid concentration increased with the addition of corn stover hydrolyzate. Glucose in corn stover hydrolyzate was depleted within $48 \mathrm{~h}$, and after $72 \mathrm{~h}$ of incubation, the total reducing sugars were almost completely consumed (Figure 1). It is notable that Bacillus sp. strain XZL4 could utilize both the two sugars simultaneously, although glucose was utilized a little faster than xylose. When the initial reducing sugar concentration condition reached $133.7 \mathrm{~g} \mathrm{~L}^{-1}$, strain XZL4 could only consume approximately $80 \mathrm{~g} \mathrm{~L}^{-1}$ reducing sugars and produce almost the same amount of lactic acid as the culture with $83 \mathrm{~g} \mathrm{~L}^{-1}$ initial total reducing sugars. Further increasing the reducing sugar concentration could not lead to the increase of lactic acid concentration, so $83 \mathrm{~g} \mathrm{~L}^{-1}$ initial total reducing sugar concentration was chosen for the subsequent studies.
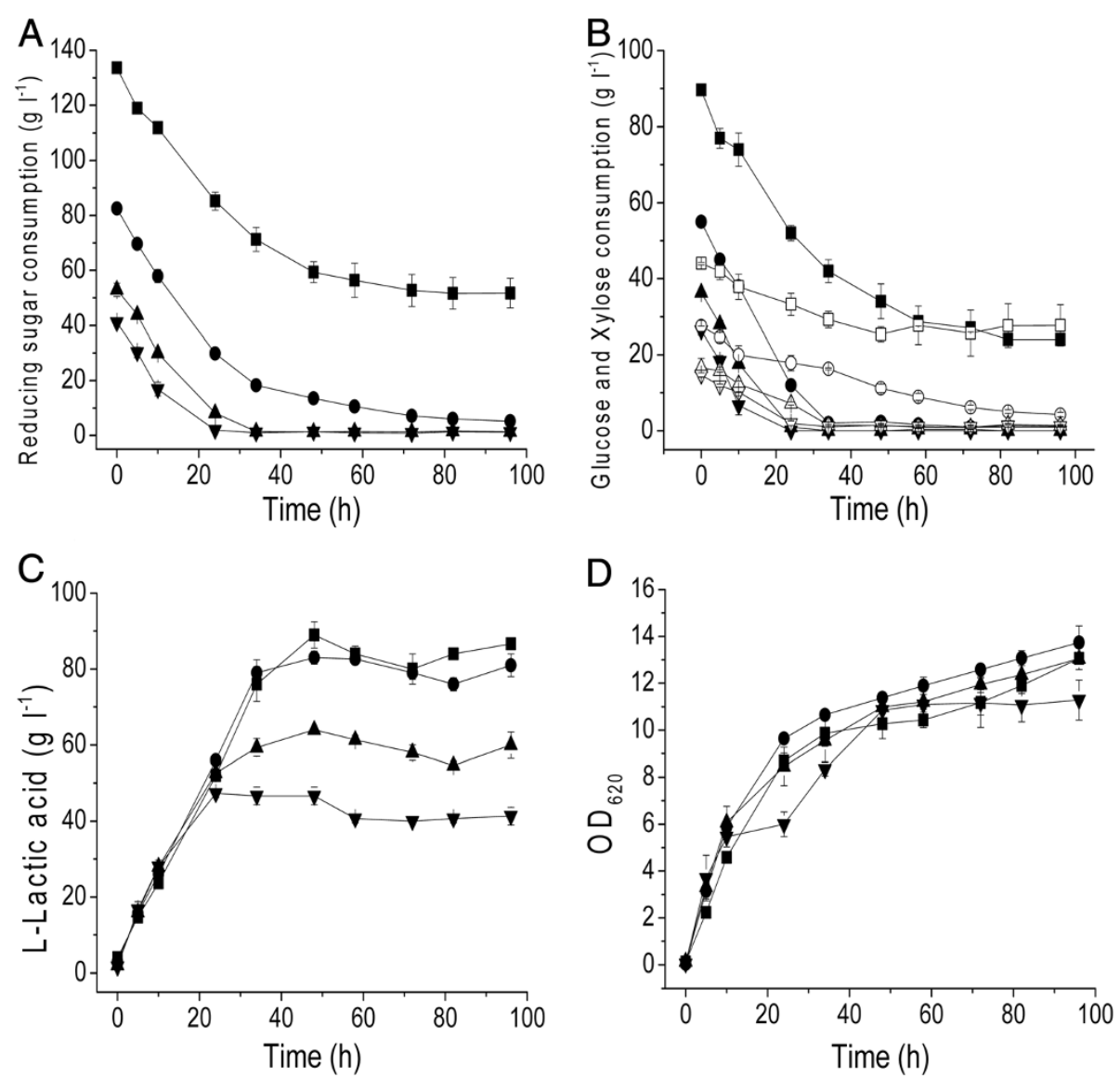

Figure 1 Effects of corn stover hydrolyzate concentrations on L-lactic acid production by Bacillus sp. XZL4. (A) The total reducing sugars consumption. (B) Glucose and xylose consumption. (C) L-lactic acid production. (D) Cell growth. Symbols represent different initial concentrations of total reducing sugars of corn stover hydrolysis $\left(\mathrm{g} \mathrm{L}^{-1}\right)$ : $133(\mathbf{\bullet}), 83(\bullet), 53(\boldsymbol{\Delta})$, and $41(\boldsymbol{\nabla})$. The symbols for xylose consumption under different initial concentrations of total reducing sugars of corn stover hydrolysis $\left(\mathrm{g} \mathrm{L}^{-1}\right)$ were $133(\square), 83(0), 53(\Delta)$, and $41(\nabla)$, respectively. The error bars in the figure indicate the standard deviations of three parallel replicates. 
Effects of nitrogen source on L-lactic acid production by strain XZL4

To reduce the cost, different kinds of organic and inorganic nitrogen sources were investigated to substitute the expensive yeast extract during L-lactic acid fermentation. Quantities of the nitrogen sources used for L-lactic acid production were added corresponding to a nitrogen concentration of $4.5 \mathrm{~g} \mathrm{~L}^{-1}$. As shown in Figure 2, when strain XZL4 was cultivated in a medium containing two kinds of the inorganic nitrogen source $\left(\left(\mathrm{NH}_{4}\right)_{2} \mathrm{SO}_{4}\right.$ and $\left.\left(\mathrm{NH}_{4}\right)_{2} \mathrm{HPO}_{4}\right)$, few L-lactic acid was produced. In the medium with $12 \mathrm{~g} \mathrm{~L}^{-1}$ dry corn syrup and $6 \mathrm{~g} \mathrm{~L}^{-1}$ soybean meal, the produced L-lactic acid concentrations were $77 \mathrm{~g} \mathrm{~L}^{-1}$ and $78 \mathrm{~g} \mathrm{~L}^{-1}$, respectively. A higher Llactic acid concentration was obtained with peanut meal
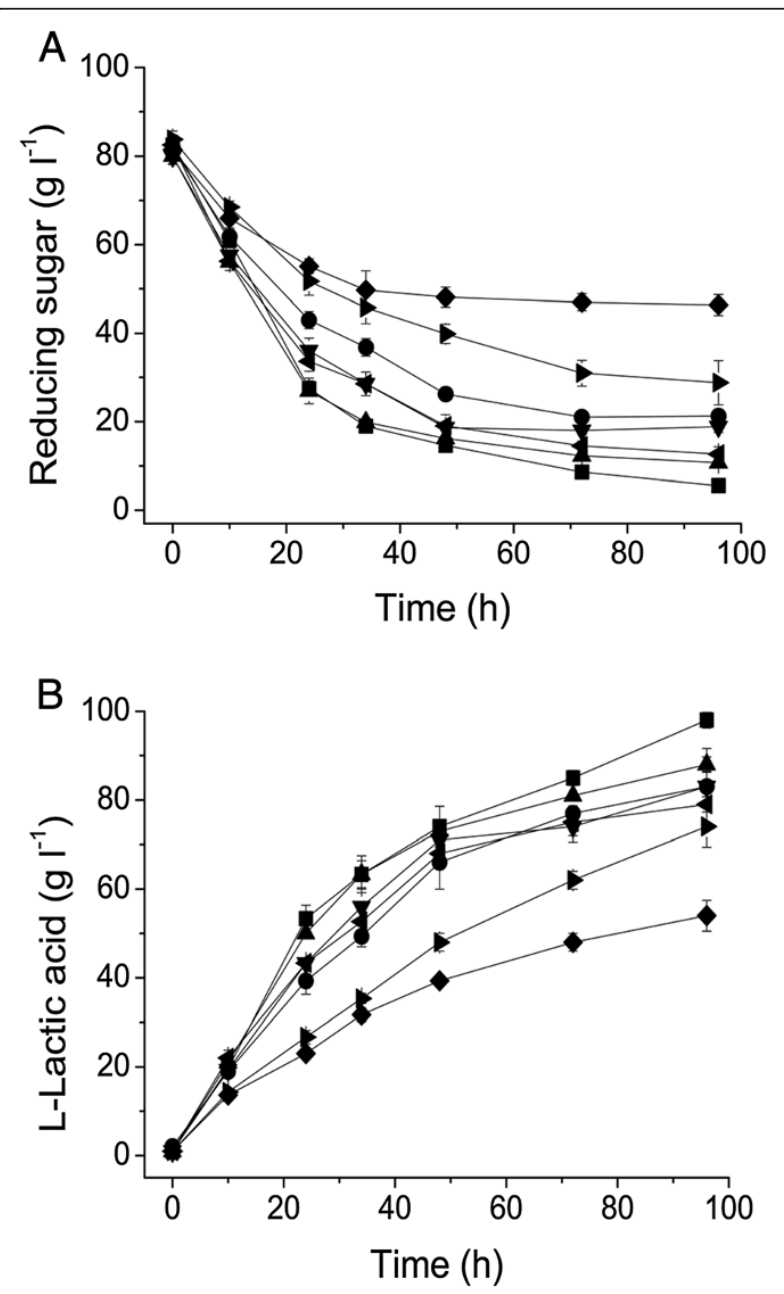

Figure 2 Effects of different nitrogen sources on L-lactic acid production by Bacillus sp. XZL4. (A) Reducing sugars consumption. (B) L-lactic acid production. Symbols represent different nitrogen sources in the fermentation medium: yeast extract $(\boldsymbol{\bullet})$, dry corn syrup $(\bullet)$, peanut meal $(\boldsymbol{\Lambda})$, soybean meal $(\boldsymbol{\nabla})$, peptone $(\bullet),\left(\mathrm{NH}_{4}\right)_{2} \mathrm{SO}_{4}(\bullet)$, and $\left(\mathrm{NH}_{4}\right)_{2} \mathrm{HPO}_{4}(\bullet)$. The error bars in the figure indicate the standard deviations of three parallel replicates. as nitrogen source although it was a little lower than that of yeast extract (Figure 2).

To investigate the effects of peanut meal concentrations on L-lactic acid production, strain XZL4 was cultivated in fermentation medium with different initial concentrations of peanut meal $\left(3.2,6.6,9.9\right.$ or $\left.13.2 \mathrm{~g} \mathrm{~L}^{-1}\right)$. Figure 3 showed that L-lactic acid concentration increased with the addition of peanut meal and $9.9 \mathrm{~g} \mathrm{~L}^{-1}$ peanut meal could meet the requirement for L-lactic acid production.

\section{L-Lactic acid production from corn stover hydrolyzate by} batch fermentation

Batch fermentations were performed in a 3-L Erlenmeyer flask containing $1 \mathrm{~L}$ fresh medium, with initial concentration of $162.5 \mathrm{~g} \mathrm{~L}^{-1}$ corn stover hydrolyzate $\left(83 \mathrm{~g} \mathrm{~L}^{-1}\right.$ of total reducing sugars). The lactic acid concentration reached $63 \mathrm{~g} \mathrm{~L}^{-1}$ within $36 \mathrm{~h}$ and the average L-lactic acid productivities of this time period were $1.86 \mathrm{~g} \mathrm{~L}^{-1} \mathrm{~h}^{-1}$
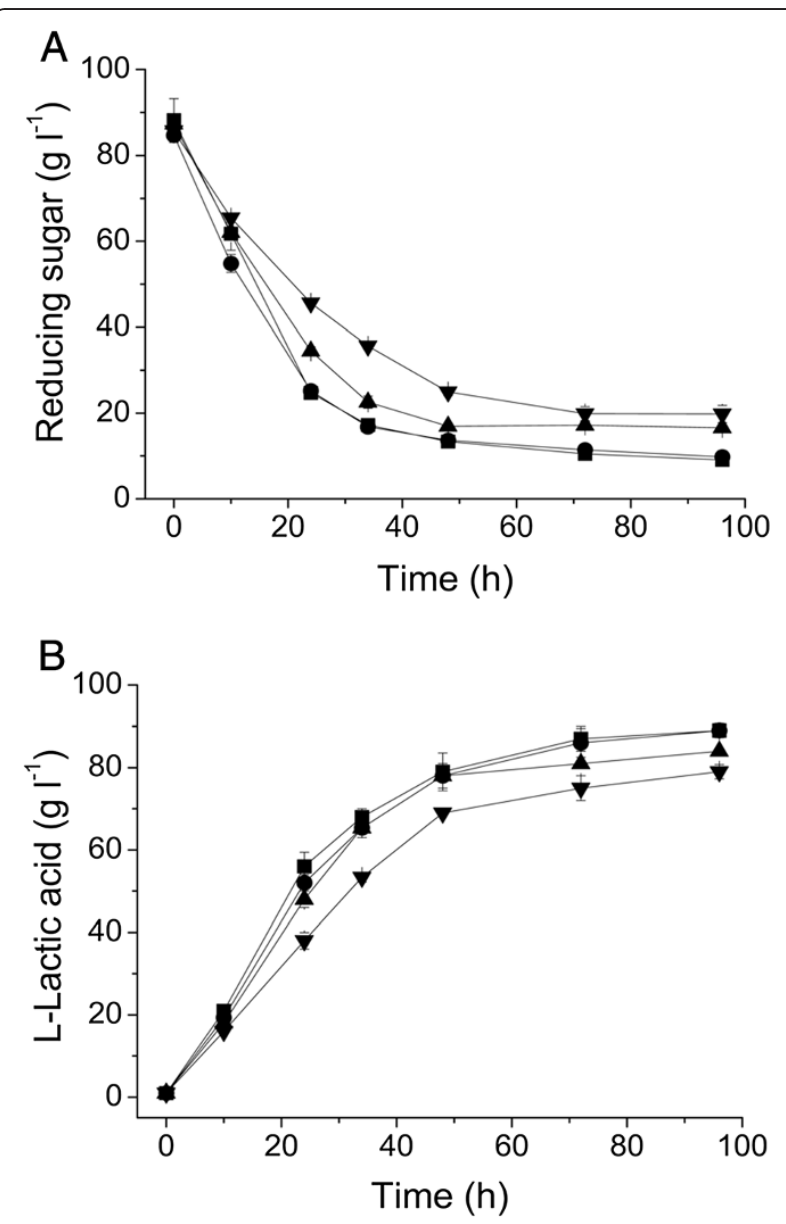

Figure 3 Effects of different nitrogen concentrations on L-lactic acid production by Bacillus sp. XZL4. (A) Reducing sugars consumption. (B) L-lactic acid production. Symbols represent different concentration of peanut meal in the fermentation medium $\left(\mathrm{g} \mathrm{L}^{-1}\right)$ : $13.2(\boldsymbol{\bullet}), 9.9(\bullet), 6.6(\boldsymbol{\Delta})$, and $3.3(\boldsymbol{\nabla})$. The error bars in the figure indicate the standard deviations of three parallel replicates. 
(Figure 4). The production of lactic acid terminated at $96 \mathrm{~h}$ with a final concentration of $81.0 \mathrm{~g} \mathrm{~L}^{-1}$ with only trace amounts of acetic acid detected $\left(<0.1 \mathrm{~g} \mathrm{~L}^{-1}\right)$, when the residual reducing sugars were almost completely consumed. The yield of lactic acid was $0.98 \mathrm{~g} \mathrm{~g}^{-1}$ total reducing sugars, which was very close to its theoretical value. No D-isomer of lactic acid was detected in the broth.

\section{Discussion}

Inexpensive underutilized agricultural by-products, such as corn stover hydrolyzate offers an attractive possibility to be used as substrate in biotechnological production of L-lactic acid, but the lactic acid yield and volumetric productivity in fermentation of agricultural by-products are generally low. The lactic acid production titers from different agricultural by-products were summarized in Table 1. Relatively low lactic acid concentrations were obtained when lime-treated wheat straw hydrolyzate (Maas et al. 2008), cellobiose (Abdel-Rahman et al. 2011), sugar cane bagasse hemicellulose hydrolyzate (Patel et al. 2004), and corn fiber hydrolyzate (Walton et al. 2010) were used for lactic acid production. Lactobacillus pentosus ATCC 8041 has been reported to produce $74.8 \mathrm{~g} \mathrm{~L}^{-1}$ lactic acid from corn stover hydrolyzate and yeast extract by fed-batch fermentation process while the low productivity $\left(0.26 \mathrm{~g} \mathrm{~L}^{-1} \mathrm{~h}^{-1}\right)$ and yield (0.65 $\left.\mathrm{g} \mathrm{g}^{-1}\right)$ were reported (Zhu et al. 2007a). To further reduce the cost, different kinds of organic and inorganic nitrogen sources were also investigated to substitute the expensive yeast extract during L-lactic acid fermentation in this study. Peanut meal is the high-protein solid residue gained from the extraction of peanut oil, which is cheap and very abundant in China. Substitution of yeast extract with peanut meal will significantly reduce the

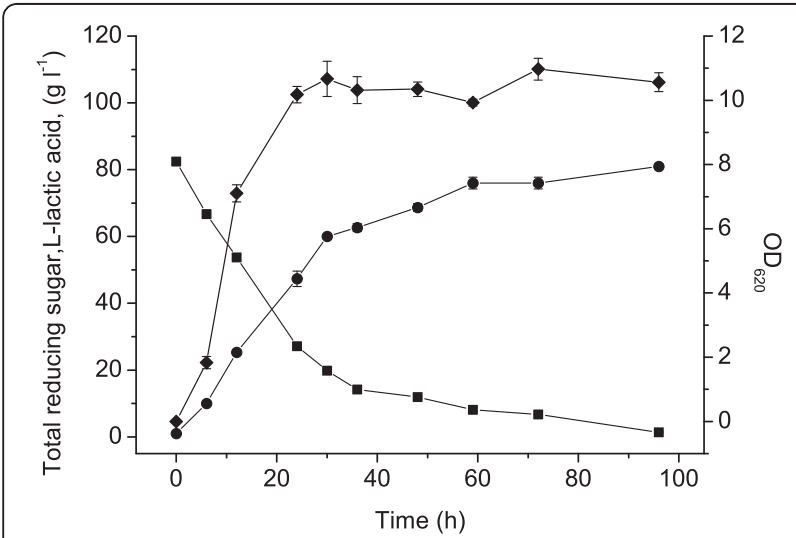

Figure 4 Batch fermentations from corn stover hydrolyzate by Bacillus sp. XZL4. Symbols represent carbohydrates consumption and cell growth in the fermentation medium $\left(\mathrm{g} \mathrm{L}^{-1}\right)$ : Reducing sugars consumption (घ), L-lactic acid production (•), and Cell growth $(\bullet)$. The error bars in the figure indicate the standard deviations of three parallel replicates. production cost of lactic acid. High concentration of D-lactic acid was obtained using peanut meal as nitrogen source by Sporolactobacillus sp. CASD (Wang et al. 2011). Bacillus sp. strain XZL4 could efficiently produce L-lactic acid from corn stover hydrolyzate with a yield of $0.98 \mathrm{~g} \mathrm{~g}^{-1}$ reducing sugars using peanut meal as sole nitrogen source. Our results demonstrated that peanut meal was an efficient and economic nitrogen alternative for polymer-grade L-lactic acid fermentation by thermophilic Bacillus strains.

Additionally, cellulose- and hemicellulose-derived carbohydrate feedstocks contained a variety of mixed sugars, mainly glucose and xylose. In order to maximize lactic acid yield and production, complete utilization of mixed sugars is essential. Carbon catabolite repression (CCR) is a common phenomenon in bacteria and very few bacteria have been reported which consume different sugars simultaneously (Görke and Stülke 2008). Therefore, for industrialization of lactic acid production from cellulosic materials, it is desirable to use CCR-positive strain for lactic acid production from mixed sugar substrates. Bacillus sp. strain XZL4 could utilize both the two sugars simultaneously, although glucose was utilized a little faster than xylose (Figure 1), proving its feasibility for L-lactic acid production from low-cost raw materials.

High L-lactic acid concentration with a volumetric productivity of $1.86 \mathrm{~g} \mathrm{~L}^{-1} \mathrm{~h}^{-1}(0-36 \mathrm{~h})$ and a product yield of $0.98 \mathrm{~g} \mathrm{~g}^{-1}$ total reducing sugars was obtained in batch fermentation by Bacillus sp. strain XZL4. The mechanisms that strain XZL4 produced L-lactic acid so effectively could be explained by the analysis results from genome sequencing data ( $\mathrm{Su}$ et al. 2011). The genome size of Bacillus sp. strain XZL4 is only $2.8 \mathrm{Mb}$. The small genome size with less genomic redundancy was thought to improve the productivity of platform chemicals or other products (Zhu et al. 2007b; Morimoto et al. 2008). The pathway of EMP is well known for its high efficiency to utilize hexose. Compared to the hexose, the pathways of utilization of pentose are more flexible. In theory, the transketolase/transaldolase pathway has higher carbon efficiency than the phosphoketolase pathway. Based on carbohydrate metabolism analysis, the key enzymes (xylose/arabinose isomerase, ribulokinase, and ribulose-5-phosphate 4-epimerase) involved in the pentose metabolite were found in the genome. The transketolase/ transaldolase pathway, instead of phosphoketolase, was in the genome, implying that strain XZL4 could utilize pentose more efficiently. Furthermore, few pyruvate-dissipating enzymes were found in strain XZL4 (Su et al. 2011). Therefore, simple and efficient carbohydrate metabolism systems, especially the absence of pyruvate decarboxylase and the existed transketolase/transaldolase pathway in thermophilic Bacillus sp. strain XZL4, should be responsible for the high-yield lactic acid production from corn stover hydrolyzate. Additionally, the absence of D-lactate dehydrogenase 
Table 1 Comparison of lactic acid production from agricultural by-products by lactic acid producing microorganisms

\begin{tabular}{|c|c|c|c|c|c|c|}
\hline \multirow[b]{2}{*}{ Substrate } & \multirow[b]{2}{*}{ Organism } & \multirow[b]{2}{*}{$\begin{array}{l}\text { Fermentation } \\
\text { process }\end{array}$} & \multicolumn{3}{|l|}{ Lactic acid } & \multirow[b]{2}{*}{ References } \\
\hline & & & $\begin{array}{l}\text { Lactic acid } \\
\text { concentration (g/L) }\end{array}$ & $\begin{array}{l}\text { Productivity } \\
\text { (g/L/h) }\end{array}$ & $\begin{array}{l}\text { Yield } \\
(\mathrm{g} / \mathrm{g})\end{array}$ & \\
\hline $\begin{array}{l}\text { lime-treated wheat straw } \\
\text { hydrolyzate }\end{array}$ & Bacillus coagulans DSM 2314 & $\begin{array}{l}\text { Continuation } \\
\text { of the SSF }\end{array}$ & $40.7^{a}$ & 0.74 & 0.43 & $\begin{array}{l}\text { Maas et al. } \\
2008\end{array}$ \\
\hline $\begin{array}{l}\text { sugar cane bagasse } \\
\text { hemicellulose hydrolyzate }\end{array}$ & $\begin{array}{l}\text { thermotolerant acidophilic Bacillus sp. } \\
\text { strain } 17 C 5\end{array}$ & Batch & $55.8^{\mathrm{a}}$ & 0.8 & 0.93 & $\begin{array}{l}\text { Patel et al. } \\
2004\end{array}$ \\
\hline cellobiose & Enterococcus mundtii QU25 & Batch & $20.4^{\mathrm{a}}$ & 3.44 & 1.04 & $\begin{array}{l}\text { Abdel-Rahman } \\
\text { et al. } 2011\end{array}$ \\
\hline reed hemicellulose liquor & $\begin{array}{l}\text { Lactococcus lactis IO-1 JCM 7638/ } \\
\text { Lactobacillus pentosus ATCC } 8041\end{array}$ & Batch & $33.0^{c}$ & 0.6 & 0.66 & $\begin{array}{l}\text { Perttunen et al. } \\
2001\end{array}$ \\
\hline wheat straw hydrolyzate & fungus Rhizopus oryzae CBS 112.07 & Batch & $6.8^{\mathrm{a}}$ & 0.14 & 0.23 & $\begin{array}{l}\text { Maas et al. } \\
2006\end{array}$ \\
\hline $\begin{array}{l}\text { hot water-extracted } \\
\text { Siberian larch }\end{array}$ & $\begin{array}{l}\text { moderate thermophile Bacillus } \\
\text { coagulans MXL-9 }\end{array}$ & SSF & $33.0^{\mathrm{a}}$ & 0.55 & 0.73 & $\begin{array}{l}\text { Walton et al. } \\
2010\end{array}$ \\
\hline paper sludge & Bacillus coagulan strains 36D1 & SSCF & $92.0^{c}$ & 0.96 & 0.77 & $\begin{array}{l}\text { Budhavaram } \\
\text { and Fan } 2009\end{array}$ \\
\hline defatted rice bran & Lactobacillus delbrueckii IFO 3202 & SSF & $28.0^{\mathrm{b}}$ & 0.78 & 0.28 & $\begin{array}{l}\text { Tanaka et al. } \\
2006\end{array}$ \\
\hline wood hydrolyzate & Enterococcus faecalis RKY1 & Batch & $93.0^{\mathrm{a}}$ & 1.7 & 0.93 & Wee et al. 2004 \\
\hline corn fiber hydrolyzate & $\begin{array}{l}\text { moderate thermophile Bacillus } \\
\text { coagulans MXL-9 }\end{array}$ & Fed batch & $45.6^{\mathrm{a}}$ & 0.21 & 0.46 & $\begin{array}{l}\text { Bischoff et al. } \\
2010\end{array}$ \\
\hline corn stover hydrolyzate & Lactobacillus pentosus ATCC 8041 & Fed batch & $74.8^{c}$ & 0.26 & 0.65 & $\begin{array}{l}\text { Zhu et al. } \\
\text { 2007a }\end{array}$ \\
\hline corn stover hydrolyzate & Bacillus sp. strain XZL4 & Batch & $81.0^{\mathrm{a}}$ & $1.86(0-36$ h $)$ & 0.98 & This work \\
\hline
\end{tabular}

SSF: Simultaneous saccharification and fermentation.

SSCF: Semi-continuous simultaneous saccharification and co-fermentation.

${ }^{a}$ L-lactic acid.

b D-lactic acid.

c DL-lactic acid.

genes in the genome of Bacillus sp. strain XZL4 also resulted in producing such high-optical purity L-lactic acid.

\section{Conclusions}

In conclusion, the highest lactic acid concentration (81.0 $\left.\mathrm{g} \mathrm{L}^{-1}\right)$ and yield (0.98 $\mathrm{g} \mathrm{g}^{-1}$ total reducing sugars) was obtained from corn stover hydrolyzate in this study. Corn stover hydrolyzate can provide an economic Llactic acid production process with cheap and renewable biomass by Bacillus sp. strain XZL4. Although the relatively higher concentrations of lactic acid were previously reported by using paper sludge (Budhavaram and Fan 2009) and wood hydrolysate (Wee et al. 2004) (Table 1), expensive yeast extract used as nitrogen source reduced their industrial applicability. And more, the absence of pyruvate decarboxylase and D-lactate hydrogenase genes in the genome demonstrated that Bacillus sp. strain XZL4 is a high-efficient polymer-grade L-lactic-acid producer from cellulosic biomass.

\section{Methods}

\section{Chemicals}

The corn stover hydrolyzate, kindly provided by Energy Research Institute of Shandong Academy of Sciences
(China), was prepared by following the procedures: 1) Pretreatment: The corn straw was grinded, then the powder was sieved and the particle sizes $\leq 2 \mathrm{~mm}$ were collected; 2) $\mathrm{HCl}$ treatment: The collected powder was treated with $6 \% \mathrm{HCl}$ at $90^{\circ} \mathrm{C}$ for $1 \mathrm{~h}$, then washed by water and adjusted to $\mathrm{pH} 4.8-5.0$; 3) Cellulase hydrolysation: The powder of corn straw was hydrolyzed with cellulase (20 FPIU/g dry mass, solid-liquid ratio was 1:50-1:10) at $50^{\circ} \mathrm{C}$ for $48 \mathrm{~h}$, and the corn straw hydrolysate was concentrated and used in this study. The contents of concentrated corn stover hydrolyzate was glucose 555.3 $\left(\mathrm{g} \mathrm{L}^{-1}\right)$, xylose $174.2\left(\mathrm{~g} \mathrm{~L}^{-1}\right)$, arabinose $19.9\left(\mathrm{~g} \mathrm{~L}^{-1}\right)$, acetic acid $7.1\left(\mathrm{~g} \mathrm{~L}^{-1}\right), 2$-furfural $1.9\left(\mathrm{~g} \mathrm{~L}^{-1}\right)$ and 5-hydroxymethyl-2-furaldehyde $0.7\left(\mathrm{~g} \mathrm{~L}^{-1}\right)$. All other chemicals were of analytical grade and commercially available.

\section{Strain and culture conditions}

Bacillus sp. strain XZL4 used in this study is a homofermentative L-lactic acid producer ( $\mathrm{Su}$ et al. 2011). The strain has been deposited in the Deutsche Sammlung von Mikroorganismen und Zellkulturen GmbH (DSM №23183). The slant was inoculated at $50^{\circ} \mathrm{C}$ after $24 \mathrm{~h}$ of incubation and stored at $4^{\circ} \mathrm{C}$. Strain XZL4 was inoculated in the culture medium containing (per liter) 50 g glucose, 
10 g yeast extract (YE), $30 \mathrm{~g}$ calcium carbonate (Wang et al. 2010b). The seed culture was prepared as follows: a loop of cells from the fully grown LB agar slant was inoculated into $30 \mathrm{~mL}$ of the above sterile medium in $100-\mathrm{mL}$ conical flasks and incubated at $50^{\circ} \mathrm{C}$ for $24 \mathrm{~h}$ without agitation. All experiments were $10 \%(\mathrm{v} / \mathrm{v})$ inoculum volume and carried out in triplicate.

\section{Effects of corn stover hydrolyzate concentrations on L-lactic acid production}

The medium used to study the effects of corn stover hydrolyze concentrations on L-lactic acid production contained 41-133 $\mathrm{g} \mathrm{L}^{-1}$ reducing sugars and $10 \mathrm{~g} \mathrm{~L}^{-1} \mathrm{YE}$. Calcium carbonate was added as $60 \%(\mathrm{w} / \mathrm{w})$ of the reducing sugars to the medium (Wang et al. 2010a). The well mixed samples were taken periodically and the concentrations of total residual reducing sugar, glucose, xylose and the L-lactic acid production were determined.

\section{Effects of different nitrogen sources on L-lactic acid production}

The variables used in the study were peanut meal and soybean meal (with $0.3 \mathrm{~g} \mathrm{~L}^{-1}$ neutral proteinase, respectively, to release the nitrogen element), peptone, yeast extract, dry corn syrup, $\left(\mathrm{NH}_{4}\right)_{2} \mathrm{SO}_{4}$ and $\left(\mathrm{NH}_{4}\right)_{2} \mathrm{HPO}_{4}$. The $162.5 \mathrm{~g} \mathrm{~L}^{-1}$ corn stover hydrolyzate (containing $83.0 \mathrm{~g} \mathrm{~L}^{-1}$ reducing sugar) and $49.5 \mathrm{~g} \mathrm{~L}^{-1} \mathrm{CaCO}_{3}$ were added. The quantities of nitrogen in all medium were controlled at $4.5 \mathrm{~g} \mathrm{~L}^{-1}$. The well mixed samples were taken periodically and the concentrations of total residual reducing sugar and the L-lactic acid production were determined.

\section{Effects of peanut meal concentrations on L-lactic acid production}

The fermentation medium for studying nitrogen concentration utilization contained 1.3-13.2 $\mathrm{g} \mathrm{L}^{-1}$ peanut meal and $162.5 \mathrm{~g} \mathrm{~L}^{-1}$ corn stover hydrolyzate, calcium carbonate was added as $60 \%(\mathrm{w} / \mathrm{w})$ of reducing sugars to the medium. Fermentations were carried out at $50^{\circ} \mathrm{C}$ under static conditions in 100-mL Erlenmeyer flasks each containing $30 \mathrm{~mL}$ medium. The well mixed samples were taken periodically and the concentrations of total residual reducing sugar and the L-lactic acid production were determined.

\section{Batch fermentation}

Batch fermentation was conducted in a 3-L Erlenmeyer flask containing $1 \mathrm{~L}$ fresh medium at $50^{\circ} \mathrm{C}$ under static conditions. The corn stover hydrolyzate $\left(162.5 \mathrm{~g} \mathrm{~L}^{-1}\right)$ containing $83.0 \mathrm{~g} \mathrm{~L}^{-1}$ of total reducing sugars was used. The medium contained $9.9 \mathrm{~g} \mathrm{~L}^{-1}$ peanut meal and $0.3 \mathrm{~g} \mathrm{~L}^{-1}$ neutral proteinase, and the culture $\mathrm{pH}$ was maintained at 5.1-6.3 by calcium carbonate present in the medium. The well mixed samples were taken periodically and the concentrations of total residual reducing sugar and L-lactic acid production were determined.

\section{Analytical methods}

The glucose and L-lactate concentration were measured by SBA-40D biosensor analyzer (Institute of Biology, Shandong Academy of Sciences, China). The total concentration of reducing sugars was measured by SGD-IV automatic analyzer of reducing sugar (Institute of Biology, Shandong Academy of Sciences, China). The xylose concentration was determined by xylose assay kit (Nanjing Jiancheng Technology Company Ltd, China). For quantification of formatic acid and acetatic acid, an Aminex HPX-87H column (Bio-Rad, Hercules, CA) was used. The column was maintained at $65^{\circ} \mathrm{C}$ and eluted with $5 \mathrm{mM}$ $\mathrm{H}_{2} \mathrm{SO}_{4}$ at a flow rate of $0.6 \mathrm{~mL} / \mathrm{min}$. Peaks were detected by Refractive Index Detector and quantified by comparison to retention times of authentic standards. The optical purity of L-lactic acid was determined by HPLC equipped with a chiral column (MCI GEL CRS10W, Japan) at $254 \mathrm{~nm}$. The mobile phase was $2 \mathrm{mM} \mathrm{CuSO}_{4}$ at a flow rate of $0.5 \mathrm{ml} / \mathrm{min}$ $\left(25^{\circ} \mathrm{C}\right)$

\section{Competing interests}

The authors declare that they have no competing interests.

\section{Authors' contributions}

PX, BY, JJ and YM participated in the design of the study. ZX and LM performed experiments. ZX, LM and BY drafted the manuscript. All authors read and approved the final manuscript.

\section{Acknowledgements}

This work was supported by grants from the Chinese National Programs for High Technology Research and Development (2011AA02A202), the Knowledge Innovation Program of the Chinese Academy of Sciences (KSCX2-EW-G-2-3) and the National Natural Science Foundation of China (30900022).

\section{Author details}

${ }^{1}$ Institute of Microbiology, Chinese Academy of Sciences, Beijing 100101 China. ${ }^{2}$ State Key Laboratory of Microbial Metabolism and School of Life Sciences and Biotechnology, Shanghai Jiao Tong University, Shanghai 200240, China. ${ }^{3}$ College of Life Science, Hebei Normal University, Shijiazhuang 050016, China.

Received: 23 September 2012 Accepted: 23 October 2012 Published: 29 October 2012

\section{References}

Abdel-Rahman MA, Tashiro Y, Zendo T, Shibata K, Sonomoto K (2011) Isolation and characterisation of lactic acid bacterium for effective fermentation of cellobiose into optically pure homo L-(+)-lactic acid. Appl Microbiol Biotechnol 89:1039-1049

Altaf M, Naveena BJ, Reddy G (2007) Use of inexpensive nitrogen sources and starch for L-(+)-lactic acid production in anaerobic submerged fermentation. Bioresour Technol 98:498-503

Altaf M, Naveena BJ, Venkateshwar M, Kumar EV, Reddy G (2006) Single step fermentation of starch to L-(+)-lactic acid by Lactobacillus amylophilus GV6 in SSF using inexpensive nitrogen sources to replace peptone and yeast extract - Optimization by RSM. Process Biochem 41:465-472

Bischoff KM, Liu S, Hughes SR, Rich JO (2010) Fermentation of corn fiber hydrolysate to lactic acid by the moderate thermophile Bacillus coagulans. Biotechnol Lett 32:823-828 
Budhavaram NK, Fan Z (2009) Production of lactic acid from paper sludge using acid-tolerant, thermophilic Bacillus coagulan strains. Bioresour Technol 100:5966-5972

Danner H, Neureiter M, Madzingaidzo L, Gartner M, Braun R (1998) Bacillus stearothermophilus for thermophilic production of L-lactic acid. Appl Biochem Biotechnol 70-72:895-903

Fitzpatrick JJ, O'Keeffe U (2001) Influence of whey protein hydrolysate addition to whey permeate batch fermentations for producing lactic acid. Process Biochem 37:183-186

Georgieva TI, Ahring BK (2007) Evaluation of continuous ethanol fermentation of dilute-acid corn stover hydrolysate using thermophilic anaerobic bacterium Thermoanaerobacter BG1L1. Appl Microbiol Biotechnol 77:61-68

Görke B, Stülke J (2008) Carbon catabolite repression in bacteria: many ways to make the most out of nutrients. Nat Rev Microbiol 6:613-624

Kwon S, Lee PC, Lee EG, Chang YK, Chang N (2000) Production of lactic acid by Lactobacillus rhamnosus with vitamin-supplemented soybean hydrolysate. Enzyme Microb Tech 26:209-215

Maas RHW, Bakker RR, Jansen MLA, Visser D, Jong D, Eggink G, Weusthuis RA (2008) Lactic acid production from lime-treated wheat straw by Bacillus coagulans: neutralization of acid by fed-batch addition of alkaline substrate. Appl Microbiol Biotechnol 78:751-758

Maas RHW, Bakker RR, Eggink G, Weusthuis RA (2006) Lactic acid production from xylose by the fungus Rhizopus oryzae. Appl Microbiol Biotechnol 72:861-868

Morimoto T, Kadoya R, Endo K, Tohata M, Sawada K, Liu S, Ozawa T, Kodama T, Kakeshita H, Kageyama Y, Manabe K, Kanaya S, Ara K, Ozaki K, Ogasawara N (2008) Enhanced recombinant protein productivity by genome reduction in Bacillus subtilis. DNA Res 15:73-81

Nancib A, Nancib N, Meziane-Cherif D, Boubendir A, Fick M, Boudrant J (2005) Joint effect of nitrogen sources and $B$ vitamin supplementation of date juice on lactic acid production by Lactobacillus casei subsp. rhamnosus. Bioresour Technol 96:63-67

Nancib N, Nancib A, Boudjelal A, Benslimane C, Blanchard F, Boudrant J (2001) The effect of supplementation by different nitrogen sources on the production of lactic acid from date juice by Lactobacillus casei subsp. rhamnosus. Bioresour Technol 78:149-153

Patel M, Ou M, Ingram LO, Shanmugam KT (2004) Fermentation of sugar cane bagasse hemicellulose hydrolysate to $L-(+)$-lactic acid by a thermotolerant acidophilic Bacillus sp. Biotechnol Lett 26:865-868

Perttunen J, Myllykoski L, Keiski RL (2001) Lactic acid fermentation of hemicellulose liquors and their activated carbon pretreatments. Eng Manuf Biotechnol 4:29-38

Qin JY, Wang XW, Zheng ZJ, Ma CQ, Tang HZ, Xu P (2010) Production of L-lactic acid by a thermophilic Bacillus mutant using sodium hydroxide as neutralizing agent. Bioresour Technol 101:7570-7576

Qin JY, Zhao B, Wang XW, Wang LM, Yu B, Ma YH, Ma CQ, Tang HZ, Sun JB, Xu P (2009) Non-sterilized fermentative production of polymer-grade L-lactic acid by a newly isolated thermophilic strain Bacillus sp. 2-6. PLoS ONE 4:e4359

Romaní A, Yáñez R, Garrote G, Alonso JL (2008) SSF production of lactic acid from cellulosic biosludges. Bioresour Technol 99:4247-4254

Su F, Xu K, Zhao B, Tai C, Tao F, Tang H, Xu P (2011) Genome sequence of the thermophilic strain Bacillus coagulans XZL4, an efficient pentose-utilizing producer of chemicals. J Bacteriol 193:6398-6399

Tanaka T, Hoshina M, Tanabe S, Sakai K, Ohtsubo S, Taniguchi M (2006) Production of D-lactic acid from defatted rice bran by simultaneous saccharification and fermentation. Bioresour Technol 97:211-217

Walton SL, Bischoff KM, Heiningen ARP, Walsum GP (2010) Production of lactic acid from hemicellulose extracts by Bacillus coagulans MXL-9. J Ind Microbiol Biotechnol 37:823-830

Wang LM, Zhao B, Li FS, Xu K, Ma CQ, Tao F, Li QG, Xu P (2011) Highly efficient production of D-lactate by Sporolactobacillus sp. CASD with simultaneous enzymatic hydrolysis of peanut meal. Appl Microbiol Biotechnol 89:1009-1017

Wang LM, Zhao B, Liu B, Yang CY, Yu B, Li QG, Ma CQ, Xu P, Ma YH (2010a) Efficient production of L-lactic acid from cassava powder by Lactobacillus rhamnosus. Bioresour Technol 101:7895-7901

Wang LM, Zhao B, Liu B, Yu B, Ma CQ, Su F, Hua DL, Li QG, Ma YH, Xu P (2010b) Efficient production of L-lactic acid from corncob molasses, a waste byproduct in xylitol production, by a newly isolated xylose utilizing Bacillus sp. strain. Bioresour Technol 101:7908-7915

Wee YJ, Yun JS, Park DH, Ryu HW (2004) Biotechnological production of L(+)-lactic acid from wood hydrolyzate by batch fermentation of Enterococcus faecalis. Biotechnol Lett 26:71-74
Zhao B, Wang LM, Ma CQ, Yang CY, Xu P, Ma YH (2010) Repeated open fermentative production of optically pure L-lactic acid using a thermophilic Bacillus sp. strain. Bioresour Technol 101:6494-6498

Zhu YM, Lee YY, Elander RT (2007a) Conversion of aqueous ammonia-treated corn stover to lactic acid by simultaneous saccharification and cofermentation. Appl Biochem Biotechnol 136-140:721-738

Zhu Y, Eiteman MA, DeWitt K, Altman E (2007b) Homolactate fermentation by metabolically engineered Escherichia coli strains. Appl Environ Microbiol 73:456-464

doi:10.1186/2193-1801-1-43

Cite this article as: Xue et al.: Efficient production of polymer-grade L-lactic acid from corn stover hydrolyzate by thermophilic Bacillus sp. strain XZL4. SpringerPlus 2012 1:43.

\section{Submit your manuscript to a SpringerOpen ${ }^{\circ}$ journal and benefit from:}

- Convenient online submission

Rigorous peer review

- Immediate publication on acceptance

- Open access: articles freely available online

- High visibility within the field

- Retaining the copyright to your article

Submit your next manuscript at springeropen.com 